\title{
Learning about Sustainability and SDG with Future Primary Education Teachers in Initial Training
}

\author{
Francisco Javier Robles-Moral \\ Departamento Didáctica de las Ciencias Experimentales, University of Murcia, 30100 Murcia, Spain; \\ franciscojavier.moral@um.es
}

\begin{abstract}
The current situation of global change, caused by our way of life and our consumption habits, has negative effects on the social, economic and environmental spheres. To alleviate these changes, from the field of education, various actions focused on sustainability are being carried out. Knowledge of sustainable environmental development is essential in the formation of citizenship, and therefore in education. That is why the purpose of this work is to introduce future primary school teachers to the Sustainable Development Goals (SDG) of the 2030 Agenda for Sustainable Development established by the UN, as an educational tool for teaching and learning sustainability in classrooms. The 4th Degree of Primary Education students worked at designing a didactic intervention, based on the development of Education for Sustainable Development Competencies (ESDC), complemented with the dissemination on Instagram of visual creations on the SDGs designed for primary education students. As a result, 5 didactic proposals and 84 posts were generated on Instagram with 1131 comments. In conclusion, in teacher training, it is necessary to become familiar with the scientific contents and the various ways of working on them in the classroom, to enable the necessary didactic transfer.
\end{abstract}

Citation: Robles-Moral, Francisco Javier. 2021. Learning about Sustainability and SDG with Future Primary Education Teachers in Initial Training. Social Sciences 10: 409. https://doi.org/10.3390/ socsci10110409

Academic Editors: Jeongsoo Yu and Ryo Ikeda

Received: 25 August 2021

Accepted: 19 October 2021

Published: 22 October 2021

Publisher's Note: MDPI stays neutral with regard to jurisdictional claims in published maps and institutional affiliations.

Keywords: sustainability; SDG; teachers training; primary education

\section{Introduction}

The world in the process of global change is a world in which the unequal exploitation and use of resources causes inequalities and imbalances in all spheres: social, economic and environmental. The current situation of global change, caused by our way of life and our consumption habits, has effects on all terrestrial systems (atmosphere, geosphere, hydrosphere and biosphere). It is argued by (Saldaña and Messina 2014), that current societies manifest a series of values and norms of conduct that have been developed along with economic development, and that have caused a change in lifestyle; the main causes by which the environment in the world continues to deteriorate, the unsustainable patterns of consumption and production. This change of anthropic origin has various faces, such as accelerated climate change, the loss of biodiversity, the unequal distribution of water and food, the overexploitation of natural resources, the loss of functionality of ecosystems, etc. (Acevedo et al. 2018).

The human being, aware of these facts, has been adopting measures and promoting initiatives both at the international and local levels to alleviate the negative effects of these changes that not only affect the environment, but also interfere with the social and economic spheres. One of these changes has been taking place in the field of education, through the integral formation of the person with special attention to sustainability, which requires a sensitivity and a special awareness of the environment, to understand it as an ecosystem and habitat that welcomes us and that must be cared for, cared for and conserved (Hernández 2019).

Since the 1970s, the UN has launched various international conferences and agreements of various kinds with the aim of reducing and eradicating inequalities and seeking environmental balance (UNESCO 1980). Among others, we can mention the United Nations 
Conference on the Human Environment or Stockholm Conference (1972), the Tbilisi Intergovernmental Conference on Environmental Education (1977); the United Nations Conference on Environment and Development, also known as the Earth Summit, was held in Rio de Janeiro, Brazil, from 3-14 June 1992; the United Nations Decade of Education for Sustainable Development (2005-2014) or the Millennium Development Goals (2000-2015) (UNESCO 1994, 2020).

Future primary education teachers must know and deepen the current development agenda, heir to the Millennium Development Goals, called the Sustainable Development Goals (SDG). The SDGs constitute an ambitious global sustainability agenda whose development was planned to begin in 2015 and conclude in 2030. The architecture of the SDGs is structured around three dimensions (economic, social and environmental). The purpose of this new development agenda is, to achieve sustainable development through the improvement of aspects such as education, equality, the eradication of poverty or the improvement of the environment (Labrador and del Valle 1995; González and Arias 2009).

Environmental education (EE), according to the successful definition established in the Moscow International Congress on Education and Training of Personnel related to the Environment (1987), can be understood as the permanent process in which individuals and communities acquire awareness of their environment and acquire the knowledge, values, skills, experience and also the determination that enables them to act individually and collectively in the resolution of present and future environmental problems (Martínez 2010; Novo and Murga 2010).

The main international antecedent of environmental education probably lies in the First UN Conference on the Environment, held in Stockholm (Sweden) in 1972, where the anthropic origin of environmental conflicts is recognized (Otero 2000). The beginning of the international Environmental Education program took place only five years later, at the First Intergovernmental Conference on Environmental Education, held in 1977 in Tbilisi (Georgia). In it, three main learning objectives can be highlighted, as follows: (i) to make the natural system known, (ii) to teach to evaluate the interrelation with society and (iii) to promote an attitudinal change (Ramos et al. 2018).

Since its inception, environmental education has contributed to the generalization of conceptual knowledge of the functioning of natural systems and, in many cases, to the evaluation of the interrelationships of anthropic activity with other elements of the system (Báez 2016). Emphasis has been placed on the transnational dimension of environmental problems and the need for a comprehensive, coherent and coordinated educational effort around the world (UN 2012). The UN itself incorporated environmental education into its activity, through the UNESCO-UNEP International Environmental Education Program (UN 1987, 2011).

In 1987, the publication of the well-known Brundtland Commission Report, Our Common Future, led to the term sustainable development (Robles et al. 2021). By this it is understood, that social and economic developments that consider the different environmental factors, while still allowing the development of current society without compromising the development of future societies (Gonzalo et al. 2017). For this reason, the objective was established to make education the main instrument that facilitates transformation to achieve a sustainable future (Vilches and Gil 2012).

Although the international community openly recognizes the relevance of education as an instrument to implement the transition towards sustainability, little progress has been made to include this idea in the educational system. It is of little use to recognize the importance of sustainability if educational subjects do not incorporate it in their study plans or if teachers do not incorporate it in their classes (Solano 2008; Gil-Pérez and Vilches 2017). This situation becomes even more serious if we consider what (González et al. 2020) point out, that without sustainability there is no possible development, and for this to exist, education is necessary; two rights, to development and to education, fundamental to people's lives (Caride 2017; Vlasyuk and Mayer 2016; Wals 2009). 
For this reason, knowledge of the essential aspects of sustainable environmental development is fundamental in the formation of citizenship, and therefore in the education of students (Fernández et al. 2021a). In this sense, it is necessary to consider the need to reinforce the training of future teachers in Knowledge of the Didactic Content (García and Martín 2016), in its multiple dimensions, such as difficulties in learning and teaching, in methodological strategies and in the characteristics of the students (Vallejo et al. 2013) and, in particular, to recognize that their training in environmental and sustainable aspects are fundamental for the formation of the citizens of the 21st century (Eusebio and Mendoza 2007; Álvarez-Otero and Lázaro-Torres 2018; Biasutti 2015). This education depends on elements such as the study plan, the curricular programs, the texts that are worked on, the didactic materials, the means and the equipment and infrastructures, among others (Vásquez et al. 2020). However, the work that teachers carry out in this regard and the importance of their training is fundamental (Calero-Llinares et al. 2019).

Thus, it is at this crossroads between education and sustainable development where what we have already called ESD (Spring 2001) arises, but the SDGs can also be implemented, since these objectives allow students to have a frame of reference to assess the sustainability of the environment (Gómez-Ruiz et al. 2021) and keep in mind an explicit horizon towards which to direct its moral motivation action, be it conservation or, mainly, prevention and rectification (Ortega 2020; Ortega-Ruíz 2009). In the current paradigm of climate and environmental emergency, sustainable development is the ultimate and urgent goal of any territory, and this must be well assumed, seeking curricular sustainability (Álvarez-Otero and Lázaro-Torres 2018).

The didactic use of the SDGs (UN 2015) is related to the constructivist paradigm of learning, according to which the students create new knowledge starting from their previous years, with the teacher's guidance and through active methodologies that help them develop a competency for learning with objects of study conceived as close to each other that increase the significance of learning and motivation (Sutinen 2008). This knowledge will be interdisciplinary (Biasutti et al. 2019) and will have a conceptual, procedural and attitudinal dimension (Biasutti and Frate 2017), as a basis for learning skills. Under this framework, teacher training, like any university degree in the European Higher Education Area (EHEA), is based on the acquisition of skills and abilities (Amor and Serrano-Rodríguez 2019). In its success, the development of didactic innovations through good educational practices acquires great importance (Zabalza 2012). This research is based on an example around landscape education with teachers in training.

From this perspective, the training of teachers in accordance with the principles of education for sustainable development (ESD) (Anđić 2020; Suryanda et al. 2020) is established as a priority for the coming years, and thus guarantees that all students acquire theoretical and practical knowledge necessary to promote sustainable development and the SDGs (Canaza-Choque 2019; Biasutti et al. 2018).

\section{Materials and Methods}

\subsection{Aims of This Work}

The main aim of the study was to ensure the Sustainable Development Goals (SDG) are known to future primary education teachers as a tool for teaching and learning sustainability in primary classrooms. Additionally, this is concreted in these specific objectives:

- Objective 1. Work on sustainability in the primary education classroom by designing activities that address current problems and solutions, which are close to the community.

- Objective 2. Promote diverse values and attitudes of respect and cultural knowledge related to sustainable development. 


\subsection{Competencies}

The inclusion of competences in higher education within the European area, through the ECTS credit system, has made it possible to create common points of reference and convergence (Cebrián and Junyent 2014). Through the work carried out linked to this study, it has allowed the development of different generic competences, from the ability to learn to the ability to improve performance and learning, including the development of study and research skills, among other capabilities. However, not only are these general competences developed, but competencies related to the area of education sciences are developed (analyze educational concepts and theories and educational policy issues in a systematic way; identify potential links between knowledge and its application to educational policies and contexts; recognize the diversity of students and the complexities of the learning process; know the different contexts in which learning can occur and the different roles of those who participate in the learning process; conduct educational research in different contexts; evaluate educational programs and materials; anticipate new educational needs and demands; be competent in various teaching/learning strategies; know the subject to be taught; be aware of the need for continuous professional development; respond to diverse needs of students; adapt the curriculum to a specific educational context) (Fernández-Fejoo and Pino-Juste 2016; Mellado et al. 2014; Robles-Moral and Fernández-Díaz 2021).

On the other hand, several authors (Cebrián and Junyent 2014; Vukelić et al. 2019) have determined a theoretical framework of ESD professional competencies (ESDC) and elaborated some key components (Cebrián and Junyent 2015):

- $\quad$ ESDC1. Understanding the different scenarios, possible futures, promoting work with different visions and scenarios for alternative and future changes;

- ESDC2. Considering the different dimensions of a problem or action, the spatial dimension (local-global) and the temporal dimension (past, present and future);

- ESDC3. The ability to identify and connect the ecological, economic and social dimensions of problems;

- $\quad$ ESDC4. Generate the conditions for systems thinking in the school environment;

- $\quad$ ESDC5. Creating the conditions for critical thinking to question assumptions and to recognize and respect different trends and views in different situations;

- $\quad$ ESDC6. Moving from awareness to action, sharing responsibilities and engaging in joint action;

- $\quad$ ESDC7. Values clarification and strengthening behavior towards sustainability thinking, mutual respect and understanding of other values;

- ESDC8. Developing teaching and learning approaches based on innovation and interdisciplinarity;

- ESDC9. Promoting reflection on one's own emotions and as a means to reach a deeper understanding of problems and situations.

\subsection{Participants}

The research was implemented with 46 degree of primary education students (ISENUniversity Centre, Spain). The students' mean age was 21.7 years $(\mathrm{SD}=0.66)$ and the female gender was dominant within the sample $(68.70 \%)$. All participants were studying the compulsory subject 'Nature Workshop' (3 ECTS credits) in 4th grade.

Participating 4th-grade teachers in training were grouped into 5 small work teams (8-10 people). Previously, participants were informed about this research and all of them gave their approval.

\subsection{Intervention Programmed}

For the design of the intervention programmed, the problem-based learning approach was identified as a valuable didactic strategy, since it allows students to explore real situations-in this case, related to sustainability. 
For the design of the activity, it is necessary to respond to the structure studied and learned throughout the degree, establishing, among other issues: target course, workshop title, learning objectives, content to be addressed (both conceptual, procedural and values), curricular framing, competences, explanation and development of the activity, necessary resources for the development, timing, evaluation system and other aspects that are considered necessary.

The work will be carried out by working groups, made up of 8-10 people, and their work will consist of preparing a dossier where they explain their workshop or sequence of activities on the SDGs. Additionally, the activity will be valued based on its adequacy to what is required, its written linguistic correction, public presentation and compliance with delivery deadlines.

For the analysis and subsequent evaluation of the didactic proposals elaborated by the students of the degree, the tool developed in Table 1 will be used. This table was adapted from the work of (Fernández et al. 2021b; Pro and Robles 2020). This tool analyzes the different aspects that students have to take into account when designing their didactic proposals, but it allows quantifying of each of the aspects (0-4) to finally be able to give a score to the proposals between 0 and 40 points, the failure score being between 0 and 19 points, and the passing grade when the total score is equal to or greater than 20 points in said tool, since the minimum necessary aspects that are required will have been covered.

Table 1. Analysis and evaluation tool of the students' didactic proposals. Adapted (Fernández et al. 2021b; Pro and Robles 2020).

\begin{tabular}{|c|c|c|c|c|c|}
\hline \multirow{2}{*}{ Item } & \multicolumn{5}{|c|}{ Assessment } \\
\hline & 0 & 1 & 2 & 3 & 4 \\
\hline Title & There are not & Generic title & Correct title & $\begin{array}{c}\text { The title is correct } \\
\text { and attractive }\end{array}$ & $\begin{array}{l}\text { It is attractive and } \\
\text { motivating }\end{array}$ \\
\hline Thematic & Not specified & $\begin{array}{l}\text { A very general theme } \\
\text { is established }\end{array}$ & $\begin{array}{l}\text { A generic theme is } \\
\text { established within } \\
\text { sustainability and } \\
\text { SDG }\end{array}$ & $\begin{array}{l}\text { The choice of the } \\
\text { theme is specified }\end{array}$ & $\begin{array}{c}\text { The choice of the } \\
\text { theme is specified } \\
\text { and justified }\end{array}$ \\
\hline Learning objectives & Not established & $\begin{array}{c}\text { Some objectives are } \\
\text { determined }\end{array}$ & $\begin{array}{c}\text { All objectives are } \\
\text { determined, but not } \\
\text { developed }\end{array}$ & $\begin{array}{c}\text { Some objectives are } \\
\text { determined and } \\
\text { developed }\end{array}$ & $\begin{array}{c}\text { All objectives are } \\
\text { determined and } \\
\text { developed }\end{array}$ \\
\hline $\begin{array}{l}\text { Contents to be } \\
\text { addressed }\end{array}$ & Not determined & $\begin{array}{c}\text { Only concepts are } \\
\text { determined }\end{array}$ & $\begin{array}{l}\text { Concepts and } \\
\text { procedures are } \\
\text { determined }\end{array}$ & $\begin{array}{l}\text { Procedures and } \\
\text { attitudes are } \\
\text { determined }\end{array}$ & $\begin{array}{c}\text { Concepts, procedures } \\
\text { and attitudes are } \\
\text { determined }\end{array}$ \\
\hline Curricular framing & $\begin{array}{l}\text { No curricular } \\
\text { element is developed }\end{array}$ & $\begin{array}{l}\text { Some curricular } \\
\text { elements are named }\end{array}$ & $\begin{array}{l}\text { Curriculum elements } \\
\text { are named, but not } \\
\text { developed }\end{array}$ & $\begin{array}{l}\text { All the curricular } \\
\text { elements are named } \\
\text { but some are } \\
\text { developed }\end{array}$ & $\begin{array}{c}\text { All curricular } \\
\text { elements are named } \\
\text { and developed }\end{array}$ \\
\hline $\begin{array}{l}\text { Sustainability } \\
\text { competences }\end{array}$ & Not developed & They are named & $\begin{array}{c}\text { They are named, but } \\
\text { the description is } \\
\text { very simple }\end{array}$ & $\begin{array}{c}\text { Short and simple } \\
\text { development }\end{array}$ & Developed correctly \\
\hline $\begin{array}{l}\text { Explanation and } \\
\text { development of the } \\
\text { activity }\end{array}$ & No explanation & $\begin{array}{l}\text { There is a very vague } \\
\text { explanation }\end{array}$ & $\begin{array}{l}\text { Explanation is } \\
\text { regular }\end{array}$ & Good explanation & $\begin{array}{l}\text { The explanation is } \\
\text { detailed and exact }\end{array}$ \\
\hline Necessary resources & Not indicated & $\begin{array}{c}\text { Some resources are } \\
\text { indicated }\end{array}$ & $\begin{array}{l}\text { All resources are } \\
\text { listed, but not } \\
\text { classified }\end{array}$ & $\begin{array}{c}\text { All resources are } \\
\text { listed, but only some } \\
\text { are classified }\end{array}$ & $\begin{array}{l}\text { All resources are } \\
\text { listed and classified }\end{array}$ \\
\hline Timing & Not established & $\begin{array}{l}\text { An approximation is } \\
\text { indicated }\end{array}$ & The timing is random & $\begin{array}{l}\text { The timing is } \\
\text { adequate }\end{array}$ & $\begin{array}{l}\text { An adequate and } \\
\text { realistic timing is } \\
\text { established }\end{array}$ \\
\hline Evaluation system & Not determined & $\begin{array}{l}\text { Some evaluative } \\
\text { elements are } \\
\text { determined }\end{array}$ & $\begin{array}{c}\text { All evaluative } \\
\text { elements are } \\
\text { determined, but not } \\
\text { developed }\end{array}$ & $\begin{array}{c}\text { Some of the } \\
\text { evaluative elements } \\
\text { are determined and } \\
\text { developed }\end{array}$ & $\begin{array}{l}\text { All the evaluative } \\
\text { elements are } \\
\text { determined and } \\
\text { developed }\end{array}$ \\
\hline
\end{tabular}


In addition, the students were requested to complete the activity with the interaction of social networks, in this case Instagram. To do this, they had to upload explanations of different SDGs to Instagram, generating their own images or presentations in order that primary school children could understand them. As an element of follow-up and dissemination of the publications and a subsequent evaluation of the publications made, the hashtag \#talleresnaturalezasostenibilidad2021 was created.

\section{Results}

\subsection{Didactic Proposal}

After the work was carried out by future primary school teachers, their didactic proposals yielded the data reflected in Table 2. In addition, this table shows the total scores and the means of both teams and item, in addition to the SD of each item and equipment. At a general level, according to the established range of achievement, or not, of the items, no item obtained a score lower than $50 \%$ of the possible points, with three items ('Thematic', 'Explanation and development of the activity' and 'Necessary resources') obtaining the maximum score of 17 out of a possible 20 points, that is, $85 \%$ of the score. While the item 'Title' is the one with the lowest score with 12 points (60\%). Regarding the teams, all obtained a passing score, since they obtained a score higher than 20 points. Team 2 obtained the highest score with a rating of 36 points out of 40 possible, but teams 4 and 5 scored 23 and 24 points, respectively, with their scores being the lowest of the five teams.

Table 2. Results of analysis and evaluation didactic proposal.

\begin{tabular}{|c|c|c|c|c|c|c|c|c|}
\hline \multirow{2}{*}{ Items } & \multicolumn{5}{|c|}{ Team } & \multirow{2}{*}{ Total } & \multirow{2}{*}{ Average } & \multirow{2}{*}{ SD } \\
\hline & 1 & 2 & 3 & 4 & 5 & & & \\
\hline Title & 2 & 3 & 3 & 2 & 2 & 12 & 2.4 & 0.5 \\
\hline Thematic & 3 & 4 & 4 & 3 & 3 & 17 & 3.4 & 0.5 \\
\hline Learning objectives & 2 & 4 & 2 & 2 & 3 & 13 & 2.6 & 0.8 \\
\hline Contents to be addressed & 3 & 4 & 3 & 2 & 2 & 14 & 2.8 & 0.8 \\
\hline Curricular framing & 3 & 4 & 3 & 2 & 2 & 14 & 2.8 & 0.8 \\
\hline ESDC & 2 & 3 & 2 & 2 & 2 & 11 & 2.2 & 0.4 \\
\hline $\begin{array}{l}\text { Explanation and } \\
\text { development of the } \\
\text { activity }\end{array}$ & 3 & 4 & 4 & 3 & 3 & 17 & 3.4 & 0.5 \\
\hline Necessary resources & 3 & 4 & 4 & 3 & 3 & 17 & 3.4 & 0.5 \\
\hline Timing & 3 & 3 & 4 & 2 & 2 & 14 & 2.8 & 0.8 \\
\hline Evaluation system & 3 & 3 & 3 & 2 & 2 & 13 & 2.6 & 0.5 \\
\hline Total & 27 & 36 & 32 & 23 & 24 & & & \\
\hline Average & 2.7 & 3.6 & 3.2 & 2.3 & 2.4 & & & \\
\hline SD & 0.4 & 0.5 & 0.8 & 0.4 & 0.5 & & & \\
\hline
\end{tabular}

When working on the different SDGs, the different work teams selected a specific SDG, and from the different targets established for each SDG they chose the most appropriate for the activity they wanted to design and the established didactic objectives. As can be seen in Table 3, the different teams selected two targets per SDG, except for team 5, which decided to work on a single target, and this has had an impact on the design of its didactic proposal, which was not as elaborate as the rest of the teams. Furthermore, it is noteworthy that two teams agreed when selecting the SDG, but not on the specific targets, which were different from each other, with team 2 focusing on the sustainable generation of products, while team 4 focused on social awareness about sustainable production, management and consumption. 
Table 3. SDGs and targets worked by the different work teams.

\begin{tabular}{|c|c|c|}
\hline Team & SDGs & Targets \\
\hline 1 & G7: Affordable and Clean Energy & $\begin{array}{l}\text { 7.2 By } 2030 \text {, substantially increase the share of } \\
\text { renewable energy in the global energy mix. } \\
\text { 7.A By 2030, enhance international cooperation to } \\
\text { facilitate access to clean energy research and } \\
\text { technology, including renewable energy, energy } \\
\text { efficiency and advanced and cleaner fossil-fuel } \\
\text { technology, and promote investment in energy } \\
\text { infrastructure and clean energy technology. }\end{array}$ \\
\hline
\end{tabular}

infrastructure and clean energy technology.

2 G12: Responsible Consumption and Production

3 G6: Clean Water and Sanitation
12.5. By 2030, substantially reduce waste generation through prevention, reduction, recycling and reuse. 12.6. Encourage companies, especially large and transnational companies, to adopt sustainable practices and to integrate sustainability information into their reporting cycle.

6.3. By 2030, improve water quality by reducing pollution, eliminating dumping and minimizing release of hazardous chemicals and materials, halving the proportion of untreated wastewater and substantially increasing recycling and safe reuse globally.

6.4. By 2030, substantially increase water-use efficiency across all sectors and ensure sustainable withdrawals and supply of freshwater to address water scarcity and substantially reduce the number of people suffering from water scarcity.

12.2. By 2030, achieve the sustainable management and efficient use of natural resources.

4 G12: Responsible Consumption and Production

12.8. By 2030, ensure that people everywhere have the relevant information and awareness for sustainable development and lifestyles in harmony with nature.

4.1. By 2030, ensure that all girls and boys complete free, equitable and quality primary and secondary education leading to relevant and goal-4 effective learning outcomes.

With respect to ESDC, students did not directly reflect these skills but they can be extracted from the analysis of the activities they proposed. The most studied sustainable competencies in the different works were 'Moving from awareness to action, sharing responsibilities and engaging in joint action' (ESDC6) and 'Developing teaching and learning approaches based on innovation and interdisciplinarity' (ESDC8), being present in $80 \%$ of the works presented. However, the sustainability competences that were not present in any of the studies were 'Considering the different dimensions of a problem or action, the spatial dimension (local-global) and the temporal dimension (past, present and future)' (ESDC2) and 'Promoting reflection on one's own emotions and as a means to reach a deeper understanding of problems and situations' (ESDC9). The ESDC9, being an item of a personal nature and self-assessment of personal emotions, was not chosen by any team for presenting great complexity when working on social networks.

In addition, as can be seen in Figure 1, team 1 and team 5 were the teams that worked the most for ESDC, with 7 and 6 of the 9 established ESDCs that each team worked on, respectively; and the team with the least ESDCs was team 4 that only worked on one ESDC, since the students who made up this team recognized that they did not correctly understand the activity to be carried out, and when they correctly understood the task to be carried out, they were near the end of the established deadline to carry out the work. 


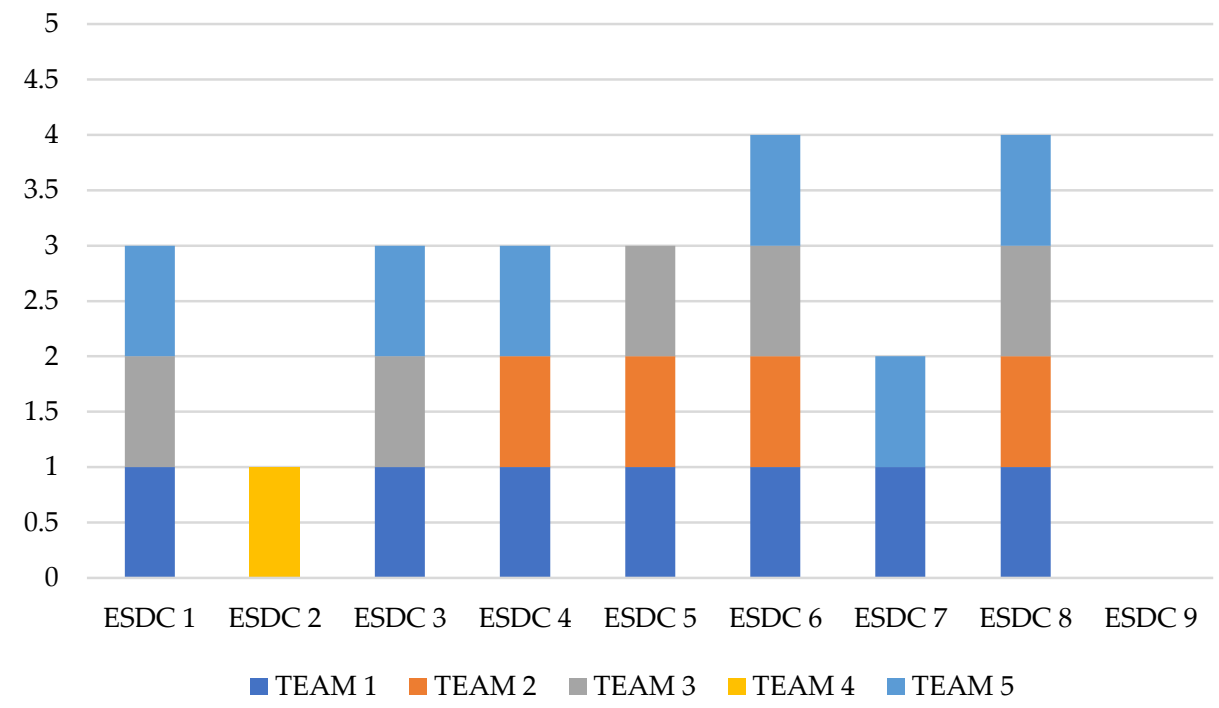

Figure 1. Accumulate graph of ESDC developed by each work team in their didactic proposals.

\subsection{Instagram Results}

The students worked for 15 days on the theme of sustainability and SDGs. Additionally, during this time, the working groups made 24 publications in total. Of these publications, as can be seen in Table 4, 84 posts were generated, with a response from more than 1100 people, in other words, 1131 likes and 67 comments were obtained.

Table 4. Results of students' posts on Instagram about SDGs.

\begin{tabular}{ccccccc}
\hline Publications & Posts & Images & Animations & Videos & Likes & Comments \\
\hline A & 10 & 10 & 0 & 0 & 64 & 3 \\
B & 6 & 6 & 0 & 0 & 26 & 3 \\
C & 1 & 1 & 0 & 0 & 45 & 1 \\
D & 1 & 1 & 0 & 0 & 33 & 2 \\
E & 7 & 5 & 0 & 2 & 52 & 2 \\
F & 8 & 8 & 0 & 0 & 27 & 1 \\
G & 1 & 1 & 0 & 0 & 37 & 1 \\
H & 1 & 1 & 0 & 0 & 35 & 1 \\
I & 1 & 1 & 0 & 0 & 35 & 4 \\
J & 9 & 9 & 0 & 0 & 36 & 4 \\
K & 1 & 1 & 0 & 0 & 18 & 1 \\
L & 7 & 5 & 2 & 0 & 32 & 4 \\
M & 1 & 1 & 0 & 0 & 97 & 19 \\
N & 1 & 1 & 0 & 0 & 50 & 6 \\
O & 1 & 1 & 0 & 0 & 56 & 4 \\
P & 3 & 3 & 0 & 0 & 98 & 2 \\
Q & 3 & 3 & 0 & 0 & 22 & 0 \\
R & 1 & 1 & 0 & 0 & 48 & 0 \\
S & 1 & 1 & 0 & 0 & 47 & 0 \\
T & 2 & 2 & 0 & 0 & 75 & 4 \\
U & 2 & 2 & 0 & 0 & 71 & 2 \\
V & 9 & 9 & 0 & 0 & 37 & 2 \\
W & 5 & 5 & 0 & 0 & 70 & 1 \\
X & 2 & 1 & 1 & 0 & 20 & 0 \\
\hline Total & 84 & 79 & 3 & 2 & 1131 & 67 \\
\hline & 24 & & & & &
\end{tabular}

In descriptive statistics, the average number of posts per group was 4.8, with an average of 3.5 posts per post. The majority of publications being static images. In addition, each publication had an average impact of 47 likes and 3 comments. 
Regarding the type of posts generated by the students, it should be remembered that Instagram is a social network based on photography, but this can be retouched to create static images, or generate animated images, or even adding videos of short duration. Thus, as can be seen in Figure 2, the type of posts generated by the different work groups were mainly images, with an average of 3 static images per post, compared to averages lower than 1 for the animated images or animations (0.12) and videos (0.08).

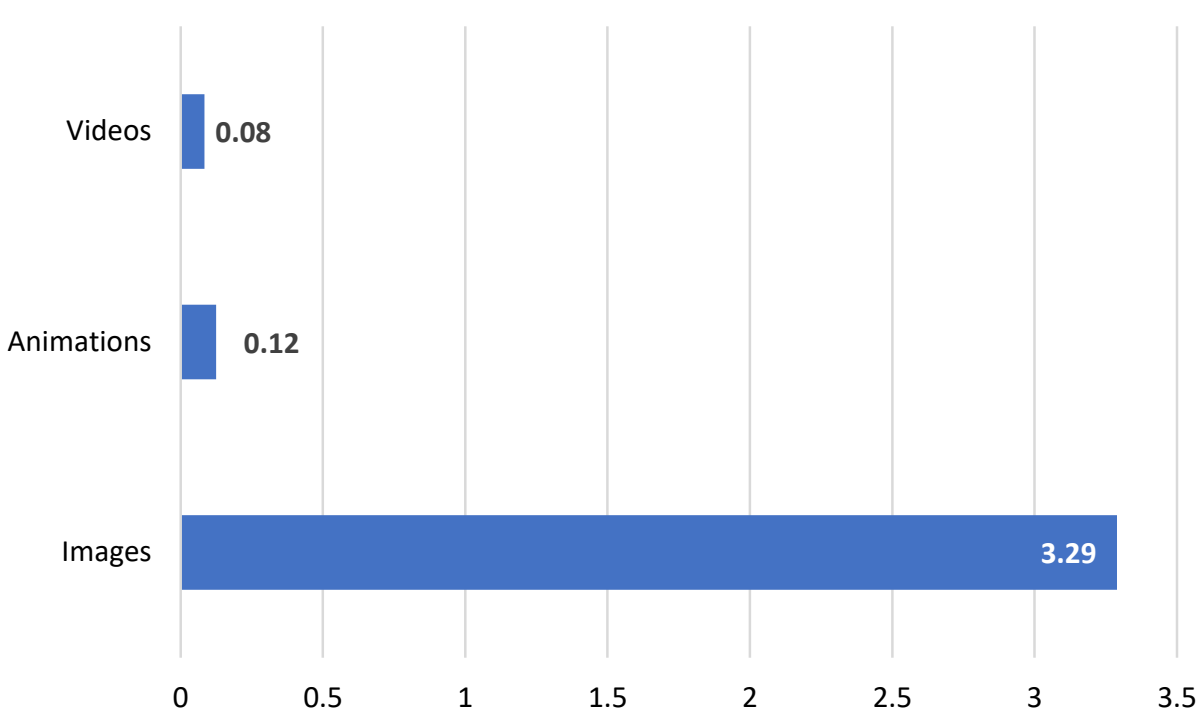

Figure 2. Graph of the average of type of posts generated by the students.

As an example of the images generated by the groups of students, Figure 3 shows two posts from one of the working groups. Although it is in the students' mother tongue, what SDGs are and what they consist of can be observed, as they are approached in an attractive way for future primary schoolchildren, using bright colors, a simple and understandable language and combining effectively the text with the images.

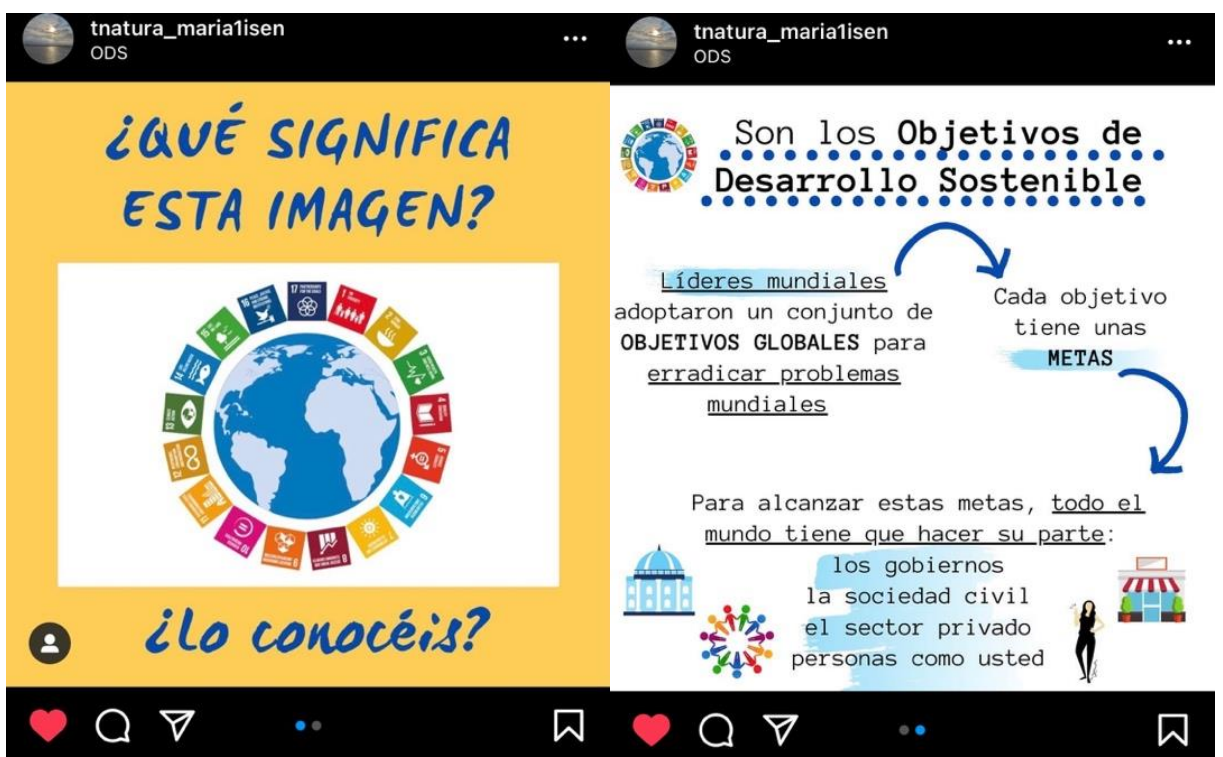

Figure 3. Example of images used by the students on Instagram. 


\section{Discussion and Conclusions}

In relation to the scientific content of a socio-environmental nature, it was observed that the students addressed a wide variety of topics, all of them related to the causes and consequences of changes of anthropic origin, such as those pointed out by (Acevedo et al. 2018). Thus, it can be stated that the participating students were already acquiring the necessary knowledge to promote sustainable development, in line with the proposal of (Vásquez et al. 2020). However, in these topics, the use of examples closest to university students, such as the environmental consequences of the textile industry, sustainable food or the consumption of plastics, stand out.

Another aspect is essential in the training of teachers, to become familiar with the scientific content and the various ways of incorporating them in the classroom; for this reason, they need to acquire a well-structured and hierarchical learning to later enable an adequate didactic transfer to their future students (Garello and Rinaudo 2013). For this reason, pedagogical tasks should be added that allow consolidating of the didactic effectiveness of the different proposals to help achieve this goal (Toma et al. 2017).

Regarding the use of Instagram in the work developed by the students, although it was one more resource that was available to the students, for them seeing the impact that they could have when developing this work allowed them to become aware of the different aspects and uses that social networks can offer, of which, educational and informative use stand out. In addition, although the number of likes received is not an objective measure to measure the impact or influence on the knowledge of the people who saw the publications, if it is true, it provides an idea of the importance that disclosure can have on social media platforms such as Instagram. Of the comments that people wrote in the publications, an example was the following comment "Thank you very much for the information in a single image, you can say a lot".

With regard to the professional competences of ESD, it has been observed that, although these competences are important in scientific education, future teachers give more importance to the competences established in the current educational legislation (González and Arias 2009; García-Esteban and Murga-Menoyo 2015), compared to those transversal competences found in the hidden curriculum (Colon 2016; Biasutti et al. 2016).

In short, the scientific-didactic study of sustainability makes it possible to assess the degree and incidence of its socio-environmental (im-)balance, questioning its state of adjustment to the characteristics of sustainable development, within the framework of the Sustainable Development Goals of the UN 2030 Agenda.

Among the limitations of the present study, the initial nature of the research and the sample size can be mentioned. Regarding future prospects, it is hoped to improve the data collection design, increase the number of participants and open the work towards other issues of great environmental importance, such as biodiversity.

Funding: This research received no external funding.

Institutional Review Board Statement: The study was conducted according to the guidelines of the Declaration of Helsinki, and approved by the Ethics Committee of ISEN.

Informed Consent Statement: Informed consent was obtained from all subjects involved in the study.

Conflicts of Interest: The author declares no conflict of interest.

\section{References}

Acevedo, Blanca Estela, Eduardo Meza, and Rosalva Enciso. 2018. Educación y cultura ambiental, binomio trascendente para el desarrollo local. Revista Educateconciencia 17: 99-108.

Álvarez-Otero, Javier, and María Luisa Lázaro-Torres. 2018. Education in Sustainable Development Goals Using the Spatial Data Infrastructures and the TPACK Model. Education Science 8: 171. [CrossRef]

Amor, María Isabel, and Rocío Serrano-Rodríguez. 2019. The generic competences in the initial teacher training. A comparative study among students, teachers and graduates of university education degree. Educación XX1 22: 239-61. [CrossRef]

Anđić, Dunjan. 2020. Continuing professional development of teachers in Education for Sustainable Development-case study of the Republic of Croatia. Teacher Development 24: 1-22. [CrossRef] 
Báez, José Enrique. 2016. La concienciación ambiental en España a principios del siglo XXI y el impacto de la crisis económica sobre la misma. Papers 101: 363-88.

Biasutti, Michele. 2015. An intensive programme on education for sustainable development: The participants' experience. Environmental Education Research 21: 734-52. [CrossRef]

Biasutti, Michele, and Sara Frate. 2017. Validity and reliability study of the Attitudes toward Sustainable Development scale. Environmental Education Research 23: 214-30. [CrossRef]

Biasutti, Michele, Theodora De Baz, and Hala Alshawa. 2016. Assessing the Infusion of Sustainability Principles into University Curricula. Journal of Teacher Education for Sustainability 18: 21-40. [CrossRef]

Biasutti, Michele, Vassilios Makrakis, Eleonora Concina, and Sara Frate. 2018. Educating academic staff to reorient curricula in ESD. International Journal of Sustainability in Higher Education 19. [CrossRef]

Biasutti, Michele, Eleonora Concina, and Sara Frate. 2019. Social Sustainability and Professional Development: Assessing a Training Course on Intercultural Education for In-Service Teachers. Sustainability 11: 1238. [CrossRef]

Calero-Llinares, María, Olga Mayoral, Àngels Ull, and Amparo Vilches. 2019. La educación para la sostenibilidad en la formación del profesorado de ciencias experimentales en Secundaria. Enseñanza de Las Ciencias 37: 157-76. [CrossRef]

Canaza-Choque, Franklin. 2019. De la educación ambiental al desarrollo sostenible: Desafíos y tensiones en los tiempos del cambio climático. Revista de Ciencias Sociales 165: 155-72. [CrossRef]

Caride, José Antonio. 2017. Educación social, derechos humanos y sostenibilidad en el desarrollo comunitario. Teoría de la Educación 29: 245-72. [CrossRef]

Cebrián, Gisela, and Mercé Junyent. 2014. Competencias profesionales en Educación para la Sostenibilidad: Un estudio exploratorio de la visión de futuros maestros. Enseñanza de las Ciencias 32: 29-49. [CrossRef]

Cebrián, Gisela, and Mercè Junyent. 2015. Competencies in Education for Sustainable Development: Exploring the Student Teachers' Views. Sustainability 7: 2768-86. [CrossRef]

Colon, Abner. 2016. The effect of hidden curriculum of environmental education in higher education students. Revista de Investigación 88: 166-75.

Eusebio, Luisa, and Augusto Mendoza. 2007. Educación ambiental: Una necesidad en la formación del maestro. The Biologist 5: 7-10. [CrossRef]

Fernández, Manuel, Francisco Javier Robles, and Enrique Ayuso. 2021a. Una propuesta para trabajar la competencia digital docente a través de Instagram y el Pensamiento Visual: El estudio de la sostenibilidad. RELATEC. Revista Latinoamericana de Tecnología Educativa 20: 87-102.

Fernández, Manuel, Francisco Javier Robles, and Enrique Ayuso. 2021b. La biodiversidad en la formación inicial del profesorado de Educación Primaria: Una iniciativa didáctica. Educatio Siglo XXI. in press.

Fernández-Fejoo, Belén, and Margarita Pino-Juste. 2016. Advantages of using active methodologies in higher education. International Journal of Learning 23: 27-39. [CrossRef]

García, Ana, and Marta Martín. 2016. Se Sienten Preparados Los Graduados En Maestro De Primaria Para Afrontar La Profesión Docente? Bordón. Revista de Pedagogía 68: 69-84. [CrossRef]

García-Esteban, Eduardo, and María Angeles Murga-Menoyo. 2015. El profesorado de educación infantil ante el desarrollo sostenible. Necesidades formativas. Enseñanza \& Teaching 33: 121-42.

Garello, María Virginia, and María Cristina Rinaudo. 2013. Autorregulación del aprendizaje, feedback y transferencia de conocimiento. Investigación de diseño con estudiantes universitarios. Revista Electrónica de Investigación Educativa 15: 131-47. Available online: http:/ / redie.uabc.mx/vol15no2/contenido-garellorinaudo.html (accessed on 14 August 2021).

Gil-Pérez, Daniel, and Amparo Vilches. 2017. Educación para la sostenibilidad y educación en derechos humanos: Dos campos que deben vincularse. Teoría y Educación 29: 79-100.

Gómez-Ruiz, María Luisa, Francisco José Morales-Yago, and María Luisa Lázaro-Torres. 2021. Outdoor Education, the Enhancement and Sustainability of Cultural Heritage: Medieval Madrid. Sustainability 13: 1106. [CrossRef]

González, Edgar, and Miguel Ángel Arias. 2009. La educación ambiental institucionalizada: Actos fallidos y horizontes de posibilidad. Perfiles Educativos 31: 58-68. [CrossRef]

González, Fernando, Raimundo Castaño-Calle, and Rosa De Castro. 2020. Taller de programación didáctica gamificada por plataforma y aula virtual. In Actas del Congreso Internacional Virtual USATIC. Zaragoza: Universidad de Zaragoza: Prensas de la Universidad de Zaragoza, pp. 56-58.

Gonzalo, Valentín, María Rosa Sobrino, Laura Benítez, and Alfonso Coronado. 2017. Revisión sistemática sobre competencias en desarrollo sostenible en educación superior. Revista Iberoamericana de Educación 73: 85-108. [CrossRef]

Hernández, Martín. 2019. Las Tecnologías de la Información y la Comunicación (TIC) para la formación de una conciencia ambiental en el contexto escolar cubano. Revista Magisterio 97: 30-44.

Labrador, Carmen, and Ángela del Valle. 1995. Labrador, Carmen, and Ángela del Valle. 1995. La educación medioambiental en los documentos internacionales. Notas para un estudio comparado. Revista Complutense de Educación 6: 75-94.

Martínez, Roger. 2010. La importancia de la educación ambiental ante la problemática actual. Revista Electrónic@ Educare XIV: 97-111. Available online: http:/ / www.redalyc.org/articulo.oa?id=194114419010 (accessed on 14 August 2021). 
Mellado, Vicente, Ana Belén Borrachero, María Brígido, Lina Melo, María Antonio Dávila, Florentina Cañada, María Carmen Conde, Emilio Costillo, Javier Cubero, Rocío Esteban, and et al. 2014. Las emociones en la enseñanza de las ciencias. Enseñanza de las Ciencias 32: 11-36.

Novo, María, and María Ángeles Murga. 2010. Educación ambiental y ciudadanía planetaria. Revista Eureka Sobre Enseñanza y Divulgación de las Ciencias 7: 179-86. [CrossRef]

Ortega, Rosario. 2020. Educación para el Desarrollo Sostenible: Del proyecto cosmopolita a la ciberconvivencia. Investigación en la Escuela 100: 11-22. [CrossRef]

Ortega-Ruíz, Rosario. 2009. La educación y los derechos humanos ante los desafíos de la convivencia. In Los Derechos Humanos en la Educación y la Cultura. Edited by José Antonio Caride. Argentina: Homo Sapiens, pp. 137-55.

Otero, Isabel. 2000. Paisaje y educación ambiental. Observatorio Medioambiental 3: 35-50.

Pro, Carlos, and Francisco Javier Robles. 2020. Qué competencias profesionales adquieren los maestros en el Grado de Educación Primaria? Paper presented at V International Symposium of Science Teaching (SIEC 2020) Celebrated from the Fifteen to Eighteen of June two Thousand and 2020, Pontevedra, Spain, June 15-18.

Ramos, Tomás, Sandra Caeiro, Sara Pires, and Nuno Videira. 2018. How are new sustainable development approaches responding to societal challenges? Sustainable Development 26: 117-21. [CrossRef]

Robles, Francisco Javier, Manuel Fernández, and Gabriel Enrique Ayuso. 2021. Desarrollo Sostenible a través de Instagram. Estudio de propuestas de futuros docentes de primaria. Edutec. Revista Electrónica De Tecnología Educativa 76: 212-27. [CrossRef]

Robles-Moral, Francisco Javier, and Manuel Fernández-Díaz. 2021. Future Primary School Teachers' Digital Competence in Teaching Science through the Use of Social Media. Sustainability 13: 2816. [CrossRef]

Saldaña, Claudia, and Sarah Messina. 2014. Cultura Ambiental. Colección 45 años de vida universitaria. Tepic: Universidad Autónoma de Nayarit.

Solano, David. 2008. Estrategias de Comunicación y Educación Para el Desarrollo Sostenible. Santiago: Oficina Regional de Educación de la UNESCO.

Spring, Joel. 2001. Globalization and Educational Rights. London: Laurence Earlbaum.

Suryanda, Ade, Eka Putri Azrai, Mutia Nuramadhan, and Ilmi Zajuli Ichsan. 2020. Analogy and critical thinking skills: Implementation learning strategy in biodiversity and environment topic. Universal Journal of Educational Research 8: 45-50. [CrossRef]

Sutinen, Ari. 2008. Constructivism and education: Education as an interpretative transformational process. Studies in Philosophy and Education 27: 1-14. [CrossRef]

Toma, Radu Bogdan, Ileana María Greca, and Jesús Ángel Meneses-Villagrá. 2017. Dificultades de maestros en formación inicial para diseñar unidades didácticas usando la metodología de indagación. Revista Eureka sobre Enseñanza y Divulgación de las Ciencias 14: 442-57. [CrossRef]

UN. 1987. Our Common Future: Brundtland Report. Geneva: United Nations General Assembly.

UN. 2011. MDG Acceleration Framework 2011. Geneva: UN, Available online: https://www1.undp.org/content/undp/es/home/ librarypage/mdg/mdg_accelerationframework0/ (accessed on 14 August 2021).

UN. 2012. The Future We Want. Outcome Document of the United Nations Conference on Sustainable Development. UN. Available online: https:/ / sustainabledevelopment.un.org/content/documents/733FutureWeWant.pdf (accessed on 14 August 2021).

UN. 2015. Objetivos de Desarrollo Sostenible. Geneva: UN, Available online: https://www.un.org/sustainabledevelopment/es/ education/ (accessed on 14 August 2021).

UNESCO. 1980. Las Grandes Orientaciones de la Conferencia de Tbilisi. París: UNESCO.

UNESCO. 1994. Ethical Guidelines for International Comparative Social Science Research in the Framework of MOST (Manage of Social Transformations). París: UNESCO.

UNESCO. 2020. Education for Sustainable Development: Partners in Action; Global Action Programme (GAP) Key Partners' Report (2015-2019). París: UNESCO.

Vallejo, Yolanda, Alba Obregoso, and Edgar Valbuena. 2013. Formación inicial de educadores infantiles que enseñan Ciencia Naturales. Enseñanza de las Ciencias: Revista de Investigación y Experiencias Didácticas Extra 0: 3606-11.

Vásquez, Claudia, María José Seckel, and Ángel Alsina. 2020. Sistema de creencias de los futuros maestros sobre Educación para el Desarrollo Sostenible en la clase de matemática. Revista Uniciencia 34: 1-15. [CrossRef]

Vilches, Amparo, and Daniel Gil. 2012. La Educación para la sostenibilidad en la universidad: El reto de la formación del profesorado. Profesorado: Revista de Currículum y Formación del Profesorado 16: 25-43.

Vlasyuk, Natalia, and Boris Mayer. 2016. Education for sustainable development: Global \& regional aspects. Novosibirsk State Pedagogical University Bulletin 6: 50-59. [CrossRef]

Vukelić, Nena, Nena Rončević, and Anamarija Vinković. 2019. Competencies for Education for Sustainability: Student Teachers' Perspectives / Collection of papers. In Quality of Education: Global Development Goals and Local Strategies. Edited by Violeta Orlović Lovren, Jan Peeters and Natasa Matović. Beograd: Univerzitet u Beogradu (Srbija) i Ghent University (Belgija), pp. 83-96.

Wals, Arjen. 2009. Review of Contexts and Structures for Education for Sustainable Development. París: UNESCO, Available online: https: / / unesdoc.unesco.org/ark:/48223/pf0000184944 (accessed on 14 August 2021).

Zabalza, Miguel Ángel. 2012. El estudio de las “buenas prácticas” docentes en la enseñanza universitaria. Revista de Docencia Universitaria 10: 17-42. [CrossRef] 